\title{
Model of investment appraisal of high-rise construction with account of cost of land resources
}

\author{
Ella Okolelova ${ }^{1, *}$ Marina Shibaeva ${ }^{1}$, and Natalya Trukhina $^{1}$ \\ ${ }^{1}$ Voronezh State Technical University, Moscow Avenue, 14, Voronezh, 394026, Russia
}

\begin{abstract}
The article considers problems and potential of high-rise construction as a global urbanization. The results of theoretical and practical studies on the appraisal of investments in high-rise construction are provided. High-rise construction has a number of apparent upsides in modern terms of development of megapolises and primarily it is economically efficient. Amid serious lack of construction sites, skyscrapers successfully deal with the need of manufacturing, office and living premises. Nevertheless, there are plenty issues, which are related with high-rise construction, and only thorough scrutiny of them allow to estimate the real economic efficiency of this branch. The article focuses on the question of economic efficiency of high-rise construction. The suggested model allows adjusting the parameters of a facility under construction, setting the tone for market value as well as the coefficient for appreciation of the construction net cost, that depends on the number of storey's, in the form of function or discrete values.
\end{abstract}

\section{Introduction}

At present moment, special attention is paid to high-rise construction, as the most promising from the point of view of rational use of land resources, the introduction of new construction technologies, the creation of a modern image of cities. High-rise construction is revving up around the world, what is due not only to the high degree of urbanization, population growth, the deficiency of suitable territories for construction in many countries of the world, but also to the desire to make cities more modern, original, comfortable, and creative, using the latest innovative solutions and technologies in the field of construction.

At the very beginning of its development, high-rise construction took into account, mainly, a lack of land resources, what is a common problem for many countries. Nowadays, not only the shortage of land forces architects and builders to begin a kind of "vertical race". This is a tribute to the modern architectural fashion, the desire to modernize the cityscape, to make them comfortable for living and working.

Each high-rise building is an intellectual product. Its construction should be approached in a comprehensive way: innovative architectural and planning solutions must be supplemented with modern engineering infrastructure, which provides the best solution for creating a reliable, safe, comfortable building, allowing its owner to achieve maximum economic efficiency.

*Corresponding author: Ella.o2011@yandex.ru 
A lot of scientists, including Russian ones: Alferov V.I., Balabanov I.T., Graboviy P.G., Panibratov Y. P., Maklakova T.G., Schukina N.M. - and their foreign colleagues: J. Friedman, N. Ordway, Pham H.X. studied the construction of high-rise buildings, its economic efficiency and relevance. So, there were stated main principles and methods of high-rise design, considered the questions of energy efficiency, complex security, fire protection, supervision over the facility and advanced building technologies and materials $[1]$.

In the work of Pham H. X. "Innovative methods for evaluating the effectiveness of design solutions in the field of high-rise construction" [2], methods for appraising the economic efficiency of design solutions for the implementation of high-rise buildings are considered.

Despite the diversity of aspects of assessing the prospects for the development of high-rise construction in various countries of the world, the problem, in our view, is not sufficiently covered. In connection with the foregoing, the aim of the work is to review and analyze the factors, that determine the prospects for high-rise construction in various countries, evaluate the negative factors as project risks, and calculate the optimal number of storeys of the building in terms of maximum economic efficiency.

The solution of this task starts with an analysis of the process of high-rise construction in the aggregate of interrelated problems, and the break down of factors, that determine the trends and growth rates of high-rise construction as a modern global strategy for the construction industry. Moreover, the risks that accompany the erection and subsequent operation of high-rise buildings should be estimated.

\section{Materials and Methods}

The theoretical methods of research, which are used in the work, are presented by theoretical analysis and generalization of the scientific literature, as well as by studying the world experience in high-rise construction. The process of investment appraisal of the construction of a high-rise building can be classified as methods of experimental and theoretical level.

High-rise buildings are complex architectural and engineering structures. The problem in this case is not only a significant rise in the cost of construction. It is necessary to take into account many factors, for example, geographical ones. As it is known, there are many seismically active zones on the Earth, on the territory of which the erection of buildings, even of standard storeys, requires additional expenses to use constructional solutions that increase the seismic resistance of buildings. Another problem of operating high-rise buildings is the wind load. Therefore, various complex architectural forms are used, based on the larger size of the building's footing relative to its top. In addition, construction of high-rise buildings must take into account the architectural landscape of the adjacent territories from the point of view of their insolation [3].

The issue of the subsequent operation of the high-rise building also requires attention. First of all, complex utility systems are used in this type of buildings, which are necessary to run the building and ensure its functionality. Unfortunately, this also leads to a significant increase in the cost of the facility.

The increase in the cost of high-rise buildings should be compensated by the use of high-tech materials and structures, modern technologies for erecting buildings and organizing production. It is the systematic approach to the construction of high-rise buildings that makes it possible to assert that this branch is the most promising to develop not only in the countries with limited land resources, but also in the countries where this issue is not so burning. 
High-rise construction allows increasing the economic impact from the sale of the object manyfold by increasing the total area of the building while reducing the costs of allocating (purchasing) a land plot for construction. At the same time, high-rise construction has many problems. It is possible to single out the positive factors that determine the profitability of the project, and negative factors that affect the growth of costs during its construction and operation [4].

Table 1. Factors that determine the efficiency of constructing high-rise buildings

\begin{tabular}{|c|c|}
\hline Positive factors & Negative factors \\
\hline \multicolumn{2}{|c|}{ Social } \\
\hline Housing (residential construction) & $\begin{array}{l}\text { Architectural and aesthetic assimilation (the } \\
\text { need to harmonize high-rise buildings with } \\
\text { old and historic ones) }\end{array}$ \\
\hline $\begin{array}{l}\text { The growth of retail, office and other type of } \\
\text { spaces (construction of commercial real estate) }\end{array}$ & Excessive urbanization of the country \\
\hline Increase in the number of jobs & $\begin{array}{l}\text { Labor migration from other sectors of the } \\
\text { national economy }\end{array}$ \\
\hline $\begin{array}{l}\text { Comfortable housing and high quality residential } \\
\text { and commercial property }\end{array}$ & Increase in social differentiation \\
\hline \multicolumn{2}{|l|}{$\begin{array}{l}\text { Change to the modern cityscape, reaching the } \\
\text { world standards }\end{array}$} \\
\hline \multicolumn{2}{|l|}{$\begin{array}{l}\text { Dynamic development of the construction } \\
\text { industry and related fields }\end{array}$} \\
\hline \multicolumn{2}{|c|}{ Economic } \\
\hline $\begin{array}{l}\text { Reducing the cost of purchasing land for } \\
\text { construction }\end{array}$ & $\begin{array}{l}\text { Shift in consumer preferences and decrease } \\
\text { in consumer demand }\end{array}$ \\
\hline $\begin{array}{l}\text { Growth of the investor's income due to upgraded } \\
\text { amenities of buildings, modern equipment, high } \\
\text { quality of service, etc. }\end{array}$ & $\begin{array}{l}\text { The level of income of the population, } \\
\text { consumption possibilities }\end{array}$ \\
\hline $\begin{array}{l}\text { Attracting foreign investment, increasing capital } \\
\text { inflows into the country }\end{array}$ & $\begin{array}{l}\text { Increase in costs when erecting high-rise } \\
\text { buildings }\end{array}$ \\
\hline $\begin{array}{l}\text { Development of intraeconomic relationships with } \\
\text { other industries }\end{array}$ & Increase in the cost of sites for construction \\
\hline \multicolumn{2}{|l|}{ Development of urban infrastructure } \\
\hline \multicolumn{2}{|c|}{ Technological } \\
\hline Use of modern technologies in construction & Complicated to construct \\
\hline Modern building materials & $\begin{array}{l}\text { Complex engineering support and } \\
\text { subsequent maintenance and operation }\end{array}$ \\
\hline $\begin{array}{l}\text { Development and implementation of innovative } \\
\text { technologies in construction, including buildings } \\
\text { engineering }\end{array}$ & Use of sturdier structures \\
\hline \multicolumn{2}{|c|}{ Geographical } \\
\hline Rational use of land resources & $\begin{array}{l}\text { Possible landscape change due to the } \\
\text { industrial development of the country }\end{array}$ \\
\hline \multicolumn{2}{|c|}{ Environmental } \\
\hline $\begin{array}{l}\text { Use of new technologies for treatment plants and } \\
\text { waste processing }\end{array}$ & $\begin{array}{l}\text { Worsen of the environment situation due to } \\
\text { the growth of manufactures, decrease in } \\
\text { natural areas and recreational zones, } \\
\text { decrease in insolation of adjacent } \\
\text { territories. }\end{array}$ \\
\hline
\end{tabular}


The complexity of high-rise construction, due to the need for large capital investments, has led to a specific form of construction organization.

The objective of initiators of such projects is a deep analysis and comparison of costs for the construction of a complex high-rise facility with the results of economic profitability from its operation. The next step to solve the problem is to construct a model for calculating the optimal height of a high-rise object from the point of view of its economic efficiency.

The cost of land resources determines the architectural and planning decisions in many ways. The issue to appraise the economic efficiency of an investor when constructing high-rise buildings and their subsequent implementation remains one of the most urgent in modern urban planning. To date, there is no universal algorithm that allows to solve with certain accuracy the issue of the optimal number of storeys and the height of the building [5].

The main objective of the investor is to solve the economic problem of finding the balance between saving the cost of acquiring land for construction, the possibility to utilize a larger number of areas on the one hand, and the cost of construction of high-rise buildings on the other hand. The increase in the cost of constructing a high-rise facility is due to the use of high-strength structures, taking into account wind effect and seismic resistance in some countries. In addition, the complexity of creating utility systems in high-rise buildings is many times more expensive than creating the same systems in buildings of low and medium height. The analysis of the factors that allow assessing the strengths and weaknesses of the construction of high-rise buildings is presented in Table 2.

Table 2. Economic impact and additional expenses.

\begin{tabular}{|l|l|}
\hline \multicolumn{1}{|c|}{ Positive economic impact } & \multicolumn{1}{c|}{ Additional expenses } \\
\hline $\begin{array}{l}\text { Reduction of the building area, saving of } \\
\text { land resources, reduction of costs to acquire } \\
\text { a land plot for construction }\end{array}$ & Increase in the cost of design works \\
\hline $\begin{array}{l}\text { Reduction of perimeter of load-bearing wall } \\
\text { structures }\end{array}$ & $\begin{array}{l}\text { Creation of more complex utility } \\
\text { systems, lift maintenance }\end{array}$ \\
\hline $\begin{array}{l}\text { Reduction of costs for roofing and } \\
\text { materials }\end{array}$ & Use of high-strength structures \\
\hline $\begin{array}{l}\text { Reduction of material costs for the floor } \\
\text { structures }\end{array}$ & $\begin{array}{l}\text { Complexity of installation, use of lifting } \\
\text { machines and mechanisms, supply of } \\
\text { materials and products }\end{array}$ \\
\hline $\begin{array}{l}\text { Localization of utility systems (water } \\
\text { supply, heating, sewerage), minimization of } \\
\text { expences for urban utility systems }\end{array}$ & $\begin{array}{l}\text { Strengthening the load-bearing structures } \\
\text { and foundation of buildings }\end{array}$ \\
\hline Increase in the amount of sold area & $\begin{array}{l}\text { Complexity to supply energy resources to } \\
\text { the upper floors of the building }\end{array}$ \\
\hline
\end{tabular}

In order for the investor to assess the efficiency of investments in high-rise construction, it is necessary to determine which factors will have a greater impact on the financial result of the project. For this purpose, a model has been developed that makes it possible to evaluate the economic efficiency of investments in the construction of a highrise building [6].

Assume the cost of a small storey building be equal to:

$$
C_{1}=S_{1} \times n_{1} \times z_{1}
$$

where $S_{1}$ is the area of the 1 st floor of a low-rise building, $\mathrm{m}^{2} ; n_{1}$ is the number of floors of a low-rise building; $z_{1}$ is the primecost of $1 \mathrm{~m}^{2}$.

The cost of a high-rise building will be:

$$
C_{2}=S_{2} \times n_{2} \times z_{2},
$$


where $S_{2}$ is the area of the 1 st floor of a multi-storey building, $\mathrm{m}^{2} ; n_{2}$ is the number of floors of a multi-storey building; $z_{2}$ is the primecost of $1 \mathrm{~m}^{2}$.

Assume the total area of buildings is the same, that is:

$$
S_{\text {total }}=S_{1} \times n_{1}=S_{2} \times n_{2}=\text { const } \Rightarrow \frac{S_{1}}{S_{2}}=\frac{n_{2}}{n_{1}},
$$

The area of the land plot intended for building is reduced in proportion to the increase in the number of storeys of the building. Consider the cost of a land plot for two construction options.

$$
L_{1}=S_{1} \times l, \quad L_{2}=S_{2} \times l,
$$

where $L_{1}$ and $L_{2}$ are the cost to acquire land for construction for low-rise buildings and high-rise ones, respectively; $l$ is the price of $1 \mathrm{~m} 2$ of a land plot.

The coefficient of savings on land allocation is proportional to the growth of the number of storeys (provided the total area of the building is constant) and is equal to:

$$
m=\frac{L_{1}}{L_{2}}=\frac{S_{1}}{S_{2}}=\frac{n_{2}}{n_{1}} .
$$

It should be taken into account that the primecost of $1 \mathrm{~m}^{2}$ increases due to the use of high-strength structures, construction of utility systems, the complexity of installation works, etc. with increasing the number of storeys of the building. Consequently,

$$
z_{2}=k z_{1},
$$

where $k$ is the coefficient of increase in the cost of construction with the increase in the number of storeys.

The total project expenses function is defined as following:

$$
y(x)=l(x)+z(x)+r(x) \text {, }
$$

where $l$ is the cost of purchasing a land plot, which is intended for building, $\$ / \mathrm{m}^{2}$; $\mathrm{z}$ is construction primecost, $\$ / \mathrm{m}^{2} ; \mathrm{r}$ are expenses to neutralize risks, $\$ ; \mathrm{x}$ is the number of storeys.

The function of total project expenses is shown in Figure 1.

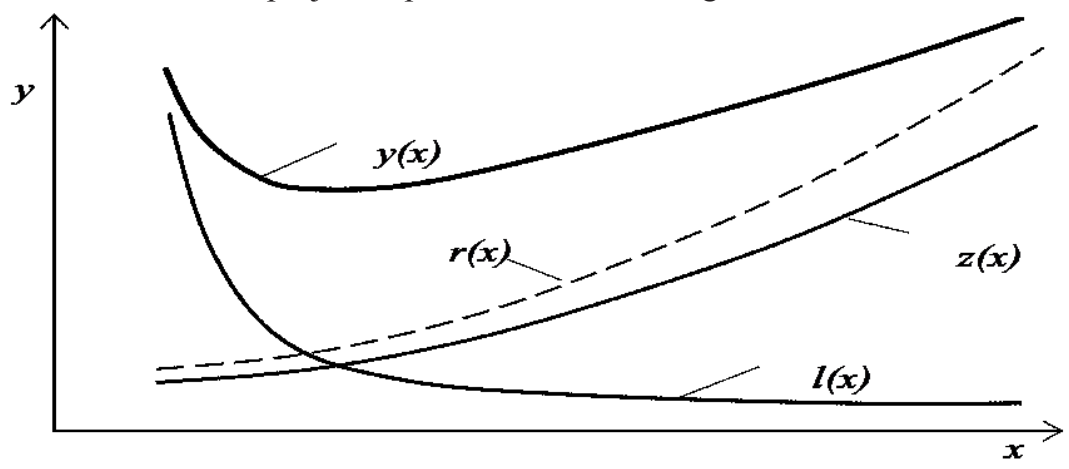

Fig. 1. Graphic definition of total expenses.

\section{Results}

The work of the model at a real high-rise facility is presented as the results of the study. As an example, the construction of a 35-storey building with certain parameters of the area, height of the building, the primecost of construction, selling price is considered. The initial data is the following:

- number of floors is 35 ; 
- the area of one floor is $1500 \mathrm{~m}^{2}$ (therefore, the total area of the building is 52.5 thousand $\mathrm{m}^{2}$ );

- Construction primecost of $1 \mathrm{~m}^{2}$ is $650 \$ / \mathrm{m}^{2}$;

- selling price of $1 \mathrm{~m}^{2}$ is $1800 \$ / \mathrm{m}^{2}$;

- coefficient of increase in price of construction is $k=1.03$.

The coefficient of increase in price $k$ according to the calculated data represents an exponential dependence of the form $k=0,9707 e^{0,0296 n}$, where $n$ is the number of floors (Fig. 2).

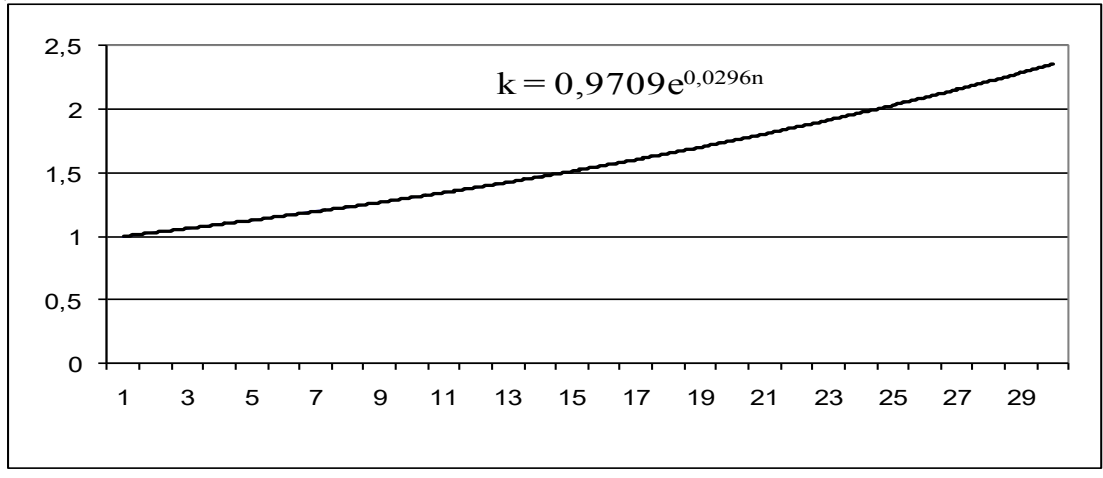

Fig. 2. Dynamics of the coefficient of increase in the primecost of construction, depending on the number of storeys of the building

Define the economic impact from the accomplishment of the building (Table 3).

Table 3. Calculation of economic efficiency from the accomplishment of a multi-storey facility depending on the number of storeys

\begin{tabular}{|c|c|c|c|c|}
\hline $\begin{array}{c}\text { Coefficient of increase in } \\
\text { price of structures }\end{array}$ & $\begin{array}{c}\text { Number of } \\
\text { storeys }\end{array}$ & $\begin{array}{c}\text { Primecost, } \\
\text { thousand } \$\end{array}$ & $\begin{array}{c}\text { Revenue, } \\
\text { thousand } \$\end{array}$ & $\begin{array}{c}\text { Profit, } \\
\text { thousand } \$\end{array}$ \\
\hline 1 & 1 & 975.0 & 2700 & 1725.0 \\
\hline 1.06 & 2 & 2070.6 & 5400 & 3329.4 \\
\hline 1.09 & 3 & 3200.5 & 8100 & 4899.5 \\
\hline 1.13 & 4 & 4397.2 & 10800 & 6402.8 \\
\hline 1.16 & 5 & 5663.9 & 13500 & 7836.1 \\
\hline 1.20 & 6 & 7003.7 & 16200 & 9196.3 \\
\hline 1.23 & 7 & 8419.9 & 18900 & 10480.1 \\
\hline 1.27 & 8 & 9915.7 & 21600 & 11684.3 \\
\hline 1.31 & 9 & 1149.9 & 24300 & 12805.1 \\
\hline 1.35 & 10 & 13161.1 & 27000 & 13838.9 \\
\hline 1.39 & 11 & 14918.1 & 29700 & 14781.9 \\
\hline 1.43 & 12 & 16770.0 & 32400 & 15630.0 \\
\hline 1.48 & 13 & 18720.7 & 35100 & 16379.3 \\
\hline 1.52 & 14 & 20774.8 & 37800 & 17025.2 \\
\hline 1.57 & 15 & 22936.6 & 40500 & 17563.4 \\
\hline 1.62 & 16 & 25210.8 & 43200 & 17989.2 \\
\hline 1.67 & 17 & 27602.2 & 45900 & 18297.8 \\
\hline 1.72 & 18 & 30115.9 & 48600 & 18484.1 \\
\hline 1.77 & 19 & 32757.1 & 51300 & 18542.9 \\
\hline & & & & \\
\hline
\end{tabular}




\begin{tabular}{|c|c|c|c|c|}
\hline $\begin{array}{c}\text { Coefficient of increase in } \\
\text { price of structures }\end{array}$ & $\begin{array}{c}\text { Number of } \\
\text { storeys }\end{array}$ & $\begin{array}{c}\text { Primecost, } \\
\text { thousand \$ }\end{array}$ & $\begin{array}{c}\text { Revenue, } \\
\text { thousand \$ }\end{array}$ & $\begin{array}{c}\text { Profit, } \\
\text { thousand \$ }\end{array}$ \\
\hline 1.82 & 20 & 35531.3 & 54000 & 18468.7 \\
\hline 1.88 & 21 & 38444.1 & 56700 & 18255.9 \\
\hline 1.93 & 22 & 41501.3 & 59400 & 17898.7 \\
\hline 1.99 & 23 & 44709.1 & 62100 & 17390.9 \\
\hline 2.05 & 24 & 48073.7 & 64800 & 16726.3 \\
\hline 2.12 & 25 & 51601.9 & 67500 & 15898.1 \\
\hline 2.18 & 26 & 55300.3 & 70200 & 14899.7 \\
\hline 2.25 & 27 & 59176.2 & 72900 & 13723.8 \\
\hline 2.32 & 28 & 63236.8 & 75600 & 12363.2 \\
\hline 2.39 & 29 & 67489.9 & 78300 & 10810.1 \\
\hline 2.46 & 30 & 71943.4 & 81000 & 9056.6 \\
\hline 2.53 & 31 & 76605.5 & 83700 & 7094.5 \\
\hline 2.61 & 32 & 81484.9 & 86400 & 4915.1 \\
\hline 2.69 & 33 & 86590.5 & 89100 & 2509.5 \\
\hline 2.77 & 34 & 91931.4 & 91800 & -131.4 \\
\hline 2.86 & 35 & 97517.3 & 94500 & -3017.3 \\
\hline
\end{tabular}

The profit graph is shown in Figure 3.

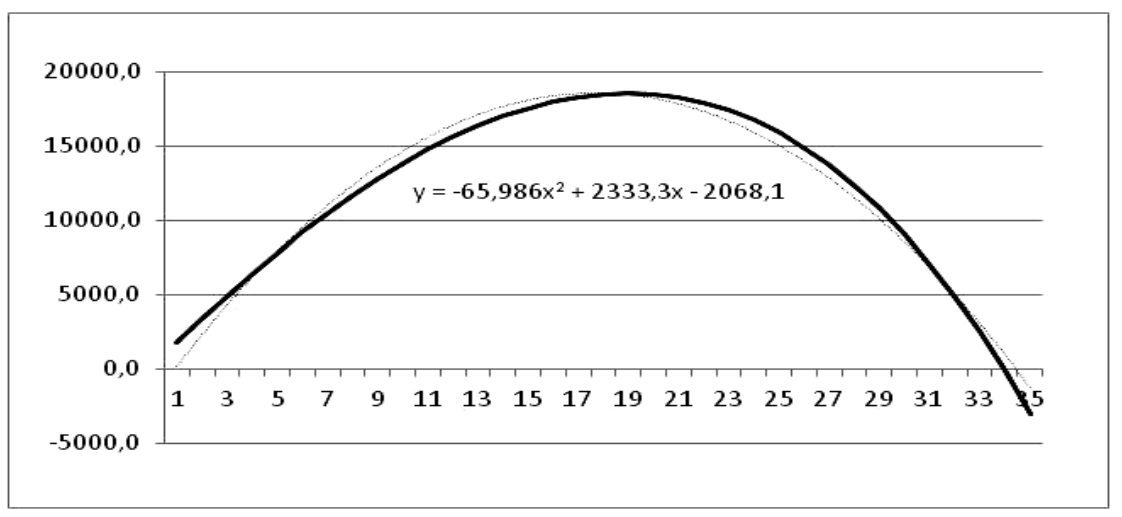

Fig. 3. The profit graph from the accomplishemnt of the facility depending on the number of storeys

Graphic interpretation of the model allows to visually evaluate the optimal number of floors. The maximum possible profit is achieved under the given conditions if the number of storeys is 19 . For a more accurate calculation, the profit function should be scrutinized, which is approximated by a second-order polynomial [7]. The first-order derivative of the function, which is represented in the graph, will be the following:

$$
\mathrm{y}^{\prime}=-131,97 \mathrm{x}+2333,3
$$

The optimal number of floors $\mathrm{x} \approx 18$ is obtained by equating the first derivative to zero and solving the resulting equation, i.e. the construction of an 18 -storey building under the given conditions will bring the developer maximum profit. Further increase in the number of storeys will gradually reduce the profitability of the project. Profit is almost zero at $\mathrm{x} \approx 34$, further increase in the number of storeys can run up the expenses on the project so drastically, that they will exceed the revenue from the sale of the facility. 
Dynamics of the $k$ coefficient in further studies showed that the efficiency of increasing the number of storeys of the building is not infinite, and has a limit (Fig. 4).

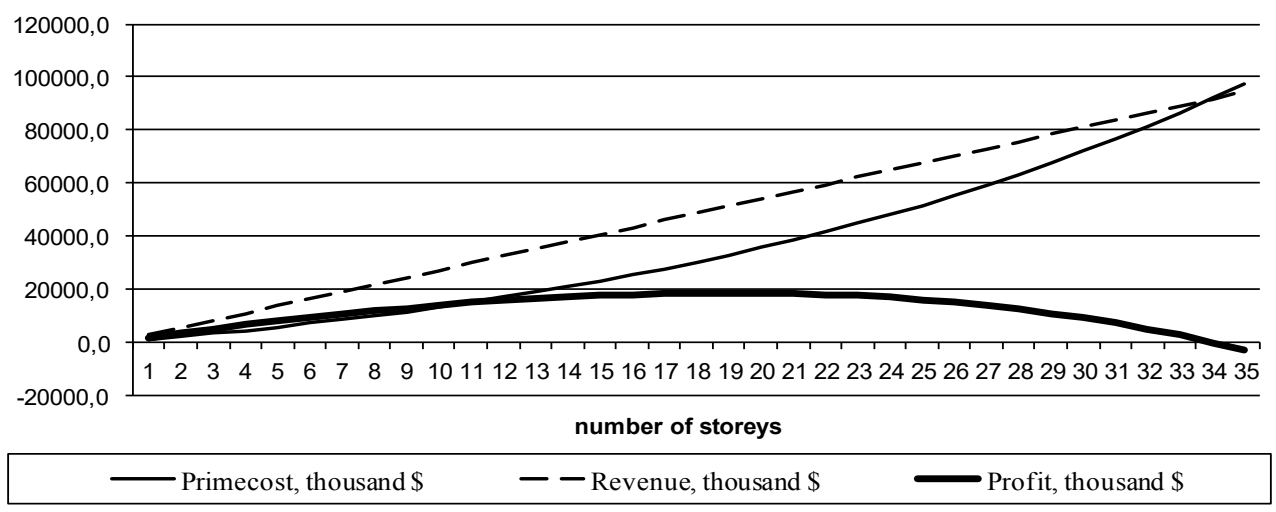

Fig.4. Graphic definition of the optimal number of storeys and the maximum profit for the investor.

Based on the preformed calculations, the optimal number of storeys of the building can be determined, which will bring the maximum profit to the investor. In this example (Figure 4), profit reaches its maximum value with an 18-storey structure. This point can be called the point of the optimal number of storeys for given parameters $S_{1}$ and $S_{2}$, as well as the dynamics of growth of the coefficient of primecost increase, which was determined by calculation.

\section{Discussions}

It is hard to call a building of 18 floors high-rise, but in this case it was required to prove the work of the model on some illustrative example. Verification of the model allows to conclude that it can be applied on a real and larger project. The suggested model allows to construct various options of architectural solutions, while linking them into a single mechanism with economic solutions $[8,9]$.

The considered example does not take into account the possibility of appreciation of the market value of $1 \mathrm{~m}^{2}$ of the area of a high-rise building, that is built with the use of new technologies and materials and has modern architecture, engineering, comfort of living, etc. In this case, the revenues from the accomplishment of this facility can significantly increase, especially from the sale of commercial space located on the first floor of the building. But at the same time, expenses will grow.

The suggested model allows to adjust all parameters and set, for example, the dynamics of the market value of $1 \mathrm{~m}^{2}$ or the coefficient of increase in the construction primecost, depending on the number of storeys, either in the form of functional dependence or in the form of discrete values.

For example, the coefficient of increase in primecost, depending on the number of storeys, is given by an exponential dependence of the form $k=e^{0,03 n}$, where $n$ is the number of storeys. Whereas, the cost of selling residential and commercial spaces of the facility increases depending on the design and comfort of the building, as well as depending on the number of storeys.

Assume that the real estate market appraisal showed the following results of appreciation of $1 \mathrm{~m}^{2}$ depending on the prestige, architecture, safficiency of the utility infrastructure and other factors: the market value of $1 \mathrm{~m}^{2}$ of the building of 10-14 floors is increased by $5 \%$; $15-19$ floors - by $10 \%$; $20-24$ floors - by $15 \%$; $25-30$ floors - by $20 \%$. For 
the practical implementation of the model, both functional dependencies and discrete values can be used.

\section{Conclusion}

The model allows combining the architectural and cost characteristics of a building into a single system, consider the real estate market conditions, and also allows evaluating the investment project of high-rise construction for the inclusion of modern smart control systems of climate, energy resources and other elements of comfort, since the market value of such an facility is growing drastically.

Factors of increasing and descreasing character for more accurate appraisal of efficiency of high-rise construction are considered and systematized. Especially important in efficiency appraising are descreasing factors, which are defined as project risks.

\section{References}

1. E. Nezhnikova, Procedia Engineering, 165, 1300-1304 (2016) doi: 10.1016/j.proeng.2016.11.854

2. S. Uvarova, V. Kanhva, M. Bovsunovskaya, Economika i predprinimatel'stvo, 9, 829831 (2014)

3. K. Gumba, O. Belyantseva, L. Kochetova, Procedia Engineering, 165, 1323-1327 (2016)

4. V. Murgul, MATEC Web of Conferences, 06002 (2017)

5. V. Kankhva, S. Uvarova, S. Belyaeva, Procedia Engineering, 165, 1046-1051 (2016)

6. N.I. Vatin, V.N. Chechevichkin, A.V. Chechevichkin, Y.S. Shilova, Magazine of Civil Engineering, 37(2) (2013) DOI: 10.5862/MCE.37.12

7. A. Borboni, M. Lancini, Journal of Vibration and Acoustics 137(3) (2015)

8. M. Ageeva, Bulletin of the University, 8, 119-118 (2011)

9. V. Kankhva, MATEC Web of Conferences, 106, 08027 doi:10.1051/matecconf/201710608027 